\title{
Intravascular large B-cell lymphoma
}

INSERM

\section{Source}

INSERM. (1999). Orphanet: an online rare disease and orphan drug data base.

Intravascular large B-cell lymphoma. ORPHA:98839

Intravascular large B-cell lymphoma (IVLBCL) is a very rare form of diffuse large B-cell lymphoma (see this term) characterized by the selective growth of lymphoma cells within the lumina of small blood vessels (especially the capillaries) that most often presents with a wide range of clinical manifestations (as potentially any tissue can be involved), with patients from Western countries more frequently manifesting with neurological and cutaneous symptoms while patients from Asian countries more frequently displaying hepatosplenomegaly and thrombocytopenia. IVLBCL is characterized by an absence of lymphadenopathy, an aggressive clinical course and a poor prognosis. 